\title{
Evaluation of Domestic Access to Pipe-Borne Water in Calabar Metropolis, Southern Nigeria
}

\author{
Inah Okon, Chukwudi G. Njoku* \\ Department of Geography and Environmental Science, University of Calabar, Calabar, Nigeria \\ Email: *chukwudi.njokupg@gmail.com
}

How to cite this paper: Okon, I. and Njoku, C.G. (2017) Evaluation of Domestic Access to Pipe-Borne Water in Calabar Metropolis, Southern Nigeria. Open Access Library Journal, 4: e3924.

https://doi.org/10.4236/oalib.1103924

Received: September 6, 2017

Accepted: December 24, 2017

Published: December 27, 2017

Copyright $\odot 2017$ by authors and Open Access Library Inc.

This work is licensed under the Creative Commons Attribution International License (CC BY 4.0).

http://creativecommons.org/licenses/by/4.0/

\begin{abstract}
Domestic access to pipe-borne water is necessary for the general well-being of residents of every community. This research investigated domestic access to the service, the relationship between socio-economic attributes and pipe-borne water characteristics as well as the contribution of four dimensions of access (availability, geographic, financial and acceptability). A total of 614 questionnaires were administered to residents of Calabar Metropolis using the systematic point sampling technique. Data were analyzed using descriptive statistics and spatial techniques. Interpolated maps were used to show variations in pipe-borne water connection, use and expenditure. Results revealed no significant relationship between the number of persons in households sampled and average volume of water used daily by respondents $(P=0.144>0.05)$. There is also no significant relationship between average volume of water used daily and the income of respondents $(p=0.03<0.05)$. Furthermore, the average monthly expenditure on pipe-borne water by respondents in the Metropolis do not significantly relate with income $(p=0.0<0.05)$. The multi-nomial logistic regression analyses revealed that a combined effect of the model of availability, geographic, financial and acceptability significantly contributes to measuring access to pipe-borne water in the Metropolis, $\chi^{2}(30)=93.455, p<$ 0.001 , with availability $(p=0.031<0.05)$ and financial $(p=0.001<0.05) \mathrm{di}$ mensions faring better. It was recommended that Cross River State Water Board Limited should not only increase the volume of water supplied to residents but also ensure that more households are connected to the service. The frequency of water supply has to be up-surged as well, with the Board distributing the water in a systematic manner, and with consideration to existing spatial variations and measures of access which have proven to be fundamental to guarantee access to water.
\end{abstract}

\section{Subject Areas}

Demography, Environmental Sciences, Human Geography, Information Science 


\section{Keywords}

Pipe-Borne Water, Dimensions of Accessibility, Access, Volume, Water Supply

\section{Introduction}

Domestic access to pipe-borne water is necessary for the general well-being of man. Water plays a critical role in all facets of life including the natural environment, global economies, food security, manufacturing and politics. The insufficiency in the availability of water for man's calls for concern as it is a serious and threatening phenomenon. Access to portable water is measured by the proportion of population with access to an adequate amount of safe water located within or at a convenient distance from the user's dwelling [1]. Water is said to be accessible when an individual is availed a volume of at least 50 litres per day [2], at a convenient distance of at least 200 meters to acquire the water where it is not present within residence (UNPD, 2000). In the same vein, the [3] report defined access to safe water as the availability of potable water of at least 30 litres per person per day, located within or at 250 - 500 meters of every household. Also, according to the [4], expenditure on water services should not exceed 5 percent of a household's income, meaning services must not affect peoples' capacity to acquire other essential goods and services, including food, housing, health services and education. Access to pipe-borne water in this study thus implies in particular the availability of clean water in adequate volume, provided through government managed infrastructure in homes or at an acceptable distance in adequate proportion, uninterruptedly and at affordable cost.

The issue today in most Nigerian cities, as is the case of Calabar Metropolis is more of a problem of access to pipe-borne water as the resource still exists in abundance in its natural state. Studies have buttressed same issue of inadequate access to pipe-borne water in developing countries and Nigeria in particular [5] [6]. Four dimensions of access such as geographic, availability, financial, and acceptability [7] were considered in this study. These dimensions which were pioneered in Penchansky and Thomas's 1981 work “The Concept of Access: Definition and Relationship to Consumer Satisfaction" [8], have received considerable attention from planners and researchers for many years. Access in itself is a measure of the quality of a service whereas availability generally measures the presence and frequency of the service in comparison to the potential users of the same. Financial and acceptability dimensions are concerned with the cost and perception of users to the service respectively, while geographic access in this scenario is the connection to the pipe-borne water network and the friction of distance or burden of travel between locations, such as residencies to locations of alternate water supply.

The United Nations Children's Emergency Fund (UNICEF) in 2013 listed 
Nigeria as one of the ten countries home to two-thirds of the global population without sufficient access to improved water sources. Nigerians have had to resort to alternative sources of water for domestic use, including private boreholes and well-sourcing groundwater aquifers, private water vendors, and rivers in some areas. Poor access to potable water has had severe consequences for the population's health outcomes and livelihoods, with children hurt the most as more than 97,000 Nigerian children die every year from diarrhea caused by unsafe water and poor sanitation [9].

Access to water in Calabar Metropolis has been hampered by institutional and physical problems. These issues cripple the availability of the essential commodity and leave residents resorting to alternative sources of water. The [10] reported that "inhabitants in the Metropolis, especially at 4 Miles, 8 Miles, IkotAnsa, parts of Federal Housing, IkotIshie, Mount Zion, Atimbo, Chamley, Afokang, etcall suffer from the inefficiency of CRSWBL service". Field survey also showed that the problem of distribution and access is also visible and compounded by the inclusion of fringes such as Atimbo-Akpabuyo, 8-Mile, Adiabo, etc., around the city which has joined the jurisdiction of the main utility. By so doing, the menu of service available to residents of such semi-urban areas is drastically reduced, worse than the sporadic services offered to the city residents. Further, areas of urban sprawl and haphazard settlement pattern such as Ikot Enebong, Ekorinim phase 2 and Lemna as well as slums in parts of Anantigha, EdimOtop and Ibisikpo have difficulties accessing pipe-borne water because of the cumbrous nature of the areas. CRSWBL no doubt has difficulty setting-up pipe networks in such areas as they are not properly laid out.

From the foregoing, it becomes necessary to examine resident's access to pipe-borne water in Calabar Metropolis in a broader scope and attempt to provide answers to questions bothering on the problem of inaccessibility to the amenity. Specific objectives of this study include: Assessment of socio-economic attributes and pipe-borne water characteristics in the Metropolis; examination of the dimensions of access (availability, geographic, financial and acceptability) and how each contributes in explaining access to pipe-borne water in the Metropolis; and an evaluation of the relationships between water use and socio-economic attributes. Calabar Metropolis is the capital of Cross River State comprises of Calabar Municipality and Calabar South Local Government Areas (LGA). As shown on Figure 1, She Metropolis lies between Longitudes $8^{\circ} 18^{\prime} 00^{\prime \prime} \mathrm{E}$ to $8^{\circ} 24^{\prime} 00^{\prime \prime} \mathrm{E}$ and Latitudes $4^{\circ} 54^{\prime} 00^{\prime \prime} \mathrm{N}$ to $5^{\circ} 04^{\prime} 00^{\prime \prime} \mathrm{N}$ and is located in the southern part of Nigeria. In 1991, the population of the city was 328,878 and a projected population of 529,362 in 2015 using a growth rate of 2.54 [11].

\section{Literature Review}

In view of the complexity of studying access to social services such as pipe-borne water, there is need for a holistic study that would consider all the dimensions of access to the service unlike most earlier studies [12] [13] [14] [15]. This is also 


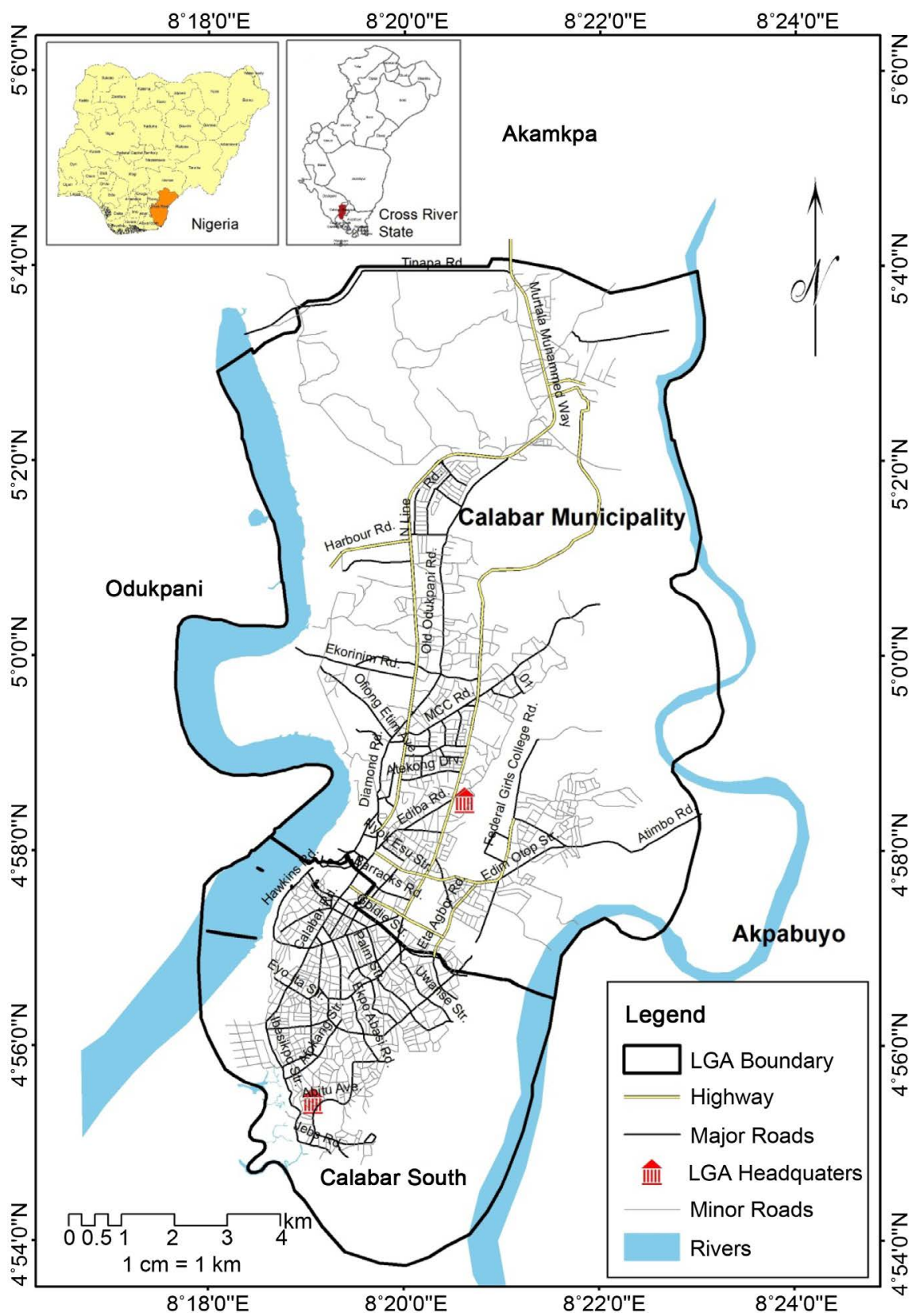

Figure 1. Map of Calabar Metropolis (Calabar south and municipality LGAs). Source: Office of the surveyor general, cross river (OSG-CR), 2015.

buttressed by the fact that some literatures on access to pipe-borne water give the impression that access is synonymous majorly with geographic impedance such as [16], a misconception that reflects the concerns of policy-makers who daily face and try to solve the problems exacerbated by the absence of water in homes. Also, in the study area and beyond, less attention has been given to spatial representation of access to pipe-borne water with maps, in as much as recent technologies abound to create such maps using available data. However, there have been specific studies bothering on access to pipe-borne water in Nigeria and beyond. 
Despite recent reports suggesting that access to improved sources of drinking water is rising in Ghana, [17] sufficed that water access remains a daily concern for many of those living in the capital region. This was deduced in their work, "chasing for water": everyday practices of water in peri-urban Ashaiman, Ghana. Conclusively, the research suggested that, although water priced outside of the official service provided is generally higher per unit, greater security may be obtained from smaller repetitive transactions as well as having the flexibility to pursue multiple source of water on a day-to-day basis. Also, the relationship between water accessibility, use and health in Muthara, Kenya was analyzed by [18]. A total of 44 respondents were surveyed and results showed that respondents do not have access to pipe-borne water, thus collect water mostly from springs or spring-fed rivers. Although some of these water sources were protected or improved, most others were not. The service levels describing accessibility showed a basic access level (around 20 litre per capita a day) based on the volume of water collected from the water source and showed a low access level (greater than 30 minutes collection time). The author concluded that although the quantities may not be as high as prescribed by World Health Organization (WHO), it may be sufficient to maintain the lifestyles and health of the people of Muthara, Kenya.

[19] reported that Nigeria has grappling issues of water scarcity across a number of its states, forcing infrastructure and long-term sustainability questions, leaving people with no other option but to acquire water from alternative sources such as wells and boreholes. For example in Makurdi, Benue State, [20] studied the contending issues of domestic water supply in the Metropolis. Their work investigated the various sources of water available in the area, its distribution across the various wards, its availability and frequency. Their findings revealed that increasing population has caused a serious water stress in the area and that the areas closer to the water board had more water supply than those areas that are farther away. In the same vein, [21] assessed access to potable water supply in Nigerian cities, evidenced from Yenagoa Metropolis of Bayelsa State. Their study was designed to determine households' access to potable water supply in Yenagoa, in terms of quality and quantity. They revealed that both the quality and quantity of water supply in Yenagoa were inadequate.

Further, [22] assessed access to safe water in Akure, Ondo State, Nigeria and revealed that, private hand dug wells were the major source of water supply in the city, most of which were not protected and treated and that the government at the state and local levels was not capable of satisfying the safe water needs of their citizenry especially as the relatively few water supply facilities provided by government were in a state of disrepair. On the way the public perceive access to safe and portable water supply, [12] studied the significant differences in perception on the basis of socio-demographic factors and geographical location in two major cities in Nigeria. They revealed that there were no significant differences in the way public view the issue of access to safe and potable water supply be- 
cause many of them acknowledge, in the course of the study, that even though they are connected to water supply, yet they do not experience regular supply of potable water.

The Geographical Distribution of Water Supply was studied by [16] in Ekiti. Results showed that only 37.1 percent of respondents from the northern senatorial region spent within 30 minutes to obtain water for domestic uses while in the central senatorial zone, 32 percent spent the same number of minutes and another 21.3 percent from the south senatorial district. The inference from further analyses was that those who spent between 30 minutes were those who had access to pipe borne water, bore holes and hand-dug wells close to their homes, while those who journeyed farther away and spent more time lacked the amenity in near proximity. [23] also worked on the Spatial Patterns of Residential Water Supply Accessibility Levels in Anambra state, Nigeria. The study determined the extent of regional imbalances in residential water supply in the area using acquired data to produce clusters. Their result showed that residential water supply accessibility pattern in Anambra state is structured into 4 zones (clusters). They thus suggested an improvement in the residential water supply in various parts of the state and urgent water resources planning to address the water poverty areas identified in the study.

In Calabar Metropolis, [24] carried out a cost analysis of domestic water supply and deduced that unconnected households spend a monthly average of between 9.3 USD and use 564 litres of water as against 4.5 USD and 741 litres consumed by connected residents. Further, that the unconnected households also cover distances between 250 and 500 meters far above threshold level of 100 meters to obtain the commodity for their usage. The study thus recommended an increase in water pipeline densification across the city, reduction of tariff charged consumers and the provision of additional stand-pipes at strategic locations to make the service rendered by municipal water board more sustainable.

In the same vein, [25] attempted to find the balance between population growth and pipe-borne water supply in Calabar between the year 2007 to 2015. Data from CRSWBL and the National Population Commission (NPC) aided deductions that there was positive relationship between population growth and pipe-borne water supply in Calabar, implying that as the population increased volume of water supplied also increased, although the accompanying increase in supply was not commensurate with water needs of the populace. The dearth of balance in water supply and the needs of the populace in the area was buttressed by the revelation of insufficiency in volume supplied in the area considering the WHO and Cross River State Technical Unit (CRSTU) standards, especially as the average volume of water availed an individual in Calabar per day in 2015 was 13 litres, way lower than the 30 litres stipulated by CRSTU and 50 litres by the WHO. [25] thus suggested an increase in the volume of water supplied, with consideration to specific water needs of the of the teeming population.

To achieve the target of the Millennium Development Goals in respect of 
adequate provision of safe drinking water by the year 2015 in developing countries, particularly Nigeria, [26] proposed the government's call for private sector participation in the provision of the utility. They thus suggested the Public-Private-People Participation for sustainable drinking water provision in $\mathrm{Ni}$ geria as the most viable option as presently operated in Lagos and Calabar. [27] also proposed a consideration of population growth and increased standard of living in projecting water demand and public enlightenment against reckless use of water after assessing the nature of portable water supply and demand in Jema LGA of Kaduna state, Nigeria and [28] recommended a reassessment of the existing pipe-borne water network to enable equitable water supply for the Calabar populace after modelling pipe-borne water distribution in Calabar Metropolis using Epanet simulation tools.

Consequent to these reviews; cost of water, increasing population, regional imbalances in supply, unavailability of pipe-borne water connection, intermittent supply, far distance to water source and distribution lapses impede on citizen's access to pipe-borne water and as a result, diminishes access in households. This is geared by the government's lackadaisical attitude towards provision of water for populace. In Nigeria, while some State governments still put efforts to achieve their mandate of providing portable water, some others have left the burden for the citizens to bear alone. A burden too heavy to bear.

\section{Materials and Methods}

This study was based on both primary and secondary sources of data. Primary data was sourced through the use of structured questionnaires that aided in collecting attribute data to answer questions on access to pipe-borne water in the Metropolis and spatial data acquisition with the use of a handheld Global Positioning System (GPS), to locate and ground-truth every questionnaire administration location acquired from the georeferenced Landsat imagery of the area. The secondary data sources encompassed existing official and unofficial statistics from publications as well as the 1991 and 2006 census data from the NPC and Cross River State Water Board Limited (CRSWBL) data such as; the monthly volume of water supplied to the Metropolis. A $70 \mathrm{~cm}$ resolution 2015 Landsat imagery of the Metropolis was also acquired from Google Earth Professional software to aid in data collection purposes.

To determine the sample size for the study, the population of Calabar South and the Municipal LGA of 1991 given by the NPC was projected to 2015 using the population growth rate of 2.54 percent per year. To make the sample size adequate for the sample population, more than one sample was taken from each sample location, such that in locations that had only one household, one sample was taken and at locations with more than one household, two samples were taken. By so doing, a total of 614 respondents were sampled at the end of the field work using the systematic random sampling technique, specifically the systematic point sampling technique which is an areal method of combining ran- 
dom and systematic sampling suitable for any spatial situation was used [29]. Distinctive to this study, a grid system was designed and overlaid on the georeferenced imagery of study area and administrative Ward-level map. The geographic coordinate of the residential buildings to be sampled were collected to aid in way-pointing to the actual location for each questionnaire administration by field assistants. This spatial sampling technique has been in practice, although their use has been limited to sampling natural occurrences. Its application in sampling human populations however is relatively novel. With increasing interest in the spatial context of geographical studies, the application of spatial sampling design becomes imperative.

Data analysis for this study incorporated both descriptive and inferential statistical tools. Firstly, socio-economic, property and water use characteristic of respondents were analysed using descriptive tables showing frequencies and percentages. The multi-nomial logistic regression model was used to deduce how the four dimensions of access contribute in explaining access to pipe borne water and to find out the dimensions that were more significant in explaining access to pipe-borne water in the area. Here, the dependent variable was the quality of access to pipe-borne water while the explanatory variables; the four dimensions of access (availability, acceptability, geographic and cost). Chi-square tests were also used to infer the relationships between household size and volume of water used, income of respondents and volume of water used and average monthly expenditure on pipe-borne water by respondents and their income. In-between, GIS techniques were used to create maps that showed spatial variation in availability, usage and cost of the service in the area. Resident's average monthly expenditure on CRSWBL pipe-borne water and expenditure on alternate sources, as well as the distance to these sources were also symbolized.

\section{Results and Discussions}

\subsection{Socio-Economic Characteristics of Respondents}

The number of persons in a particular household is a great deal to the water consumption pattern of such home. As depicted on Table 1 , as much as 56.8 respondents had between 4 and 6 persons in their household, 24.1 percent less than 3 and 19.1 percent of the respondents having more than 7 persons in their household. There was no clear cut distinction in the average income of respondents in the Metropolis, apart from the few 8.1 percent that earn a living of more than 81,000 Naira monthly. 28.7 percent of the respondents earn between 31,000 Naira to 50,000 Naira monthly and as much as 20.8 percent earn less than 10,000 Naira on average monthly. The income of individuals also has strong linkages with water use in any particular area, as water is mostly a service paid for either in monetary terms or by physical efforts, or sometimes both.

Also, as portrayed on Table 1, Literacy level was noticeably high in the area where only 0.3 percent had some sort of informal education. Others had different levels of formal education with 51 percent having attained higher education. 
Table 1. Socio economic characteristics of respondents.

\begin{tabular}{|c|c|c|c|}
\hline $\mathrm{S} / \mathrm{N}$ & Socio-Economic Variable & Frequency & Percentage \\
\hline \multirow[t]{5}{*}{$\mathrm{C}$} & \multicolumn{3}{|c|}{ Household Size } \\
\hline & 0 to 3 & 148 & 24.1 \\
\hline & 4 to 6 & 349 & 56.8 \\
\hline & 7 above & 117 & 19.1 \\
\hline & Total & 614 & 100 \\
\hline \multirow[t]{7}{*}{ G } & \multicolumn{3}{|c|}{ Income Range of Respondents (N) } \\
\hline & Less than 10,000 & 128 & 20.8 \\
\hline & 10,000 to 30,000 & 161 & 26.2 \\
\hline & 31,000 to 50,000 & 176 & 28.7 \\
\hline & 51,000 to 80,000 & 99 & 16.1 \\
\hline & Greater than 81,000 & 50 & 8.1 \\
\hline & Total & 614 & 100 \\
\hline \multirow[t]{6}{*}{$\mathrm{H}$} & \multicolumn{3}{|c|}{ Education Status of Respondents } \\
\hline & Primary School & 26 & 4.2 \\
\hline & Secondary School & 273 & 44.5 \\
\hline & Higher Education & 313 & 51 \\
\hline & Informal Education & 2 & 0.3 \\
\hline & Total & 614 & 100 \\
\hline \multirow[t]{6}{*}{$\mathrm{C}$} & \multicolumn{3}{|c|}{ Number of Rooms in House } \\
\hline & 1 Bedroom & 110 & 17.9 \\
\hline & 2 Bedroom & 253 & 41.2 \\
\hline & 3 Bedroom & 205 & 33.4 \\
\hline & 4 Bedroom and above & 46 & 7.5 \\
\hline & Total & 614 & 100 \\
\hline \multirow[t]{4}{*}{$\mathrm{D}$} & \multicolumn{3}{|c|}{ Number of Kitchens in House } \\
\hline & 1 & 608 & 99 \\
\hline & 2 & 6 & 1 \\
\hline & Total & 614 & 100 \\
\hline \multirow[t]{5}{*}{ E } & \multicolumn{3}{|c|}{ Number of Bathrooms in House } \\
\hline & 1 & 486 & 79.2 \\
\hline & 2 & 121 & 20.5 \\
\hline & 3 and above & 4 & 0.7 \\
\hline & Total & 614 & 100 \\
\hline
\end{tabular}

Source: Author's field computation, 2016.

The city thus lives up to expectations being one of the first locations of contact with missionaries and education in Nigeria. It is expected that where literacy is high, sanitation practices are correspondingly good. Similarly, 41.2 percent of respondents had two bedrooms in their houses and only 7.5 percent having 4 and more bedrooms. In the same vein, 1 percent of respondents do not have 
kitchens while most of the households (99 percent) had kitchens while 78.8 and 78.7 percent of households had at least 1 bathroom and toilet in their homes respectively. The implication of a larger house with more rooms, toilets, bathrooms and kitchen is the possible need for more water for different purposes in the house. Likewise, sanitation standards with regards to availability of toilets and bathrooms can be said to be high in the Metropolis considering the fact that a very high percentage of respondents have at least 1 bathroom and toilet.

\subsection{CRSWBL Pipe-Borne Water Service and Utility}

Analyses revealed that 48.5 percent were connected to the CRSWBL service while 51.5 percent were either disconnected or have never been connected to the pipe-borne water network. Pictured in Figure 2 is the spatial variation of the connection of residents to the pipe-borne water service in Calabar. Visibly, Wards 3, 5, 6 and 7 of the Municipality are least connected to the service, while Wards 1, 2, 3, 5, and 9 of Calabar South had the highest number of connection. This depicts the level of geographic access to pipe-borne water in the area. The much respondents not connected to the network are either residents in new areas of the city, areas of sprawl or residencies where the service has failed, thus an outright intentional disconnection. It is worthy to note however, that, connection to the service does not invariably guarantee access to pipe-borne water.

It was also observed that pipe-borne water fell short of being the most important source of water in the Metropolis as only 30 percent of respondents majorly use the government provided service. Hand-dug wells were the least used sources of water in the area with just 1.1 percent, while boreholes within and away from residences recorded the highest use with 67.8 percent. While some residents use pipe borne water, they also acquire water from other sources. This is because of the intermittency characterized of the supply. Thus when pipe-borne water is not available, they simply reach out to their alternatives. 8.6 percent of respondents use their personally powered boreholes while 85.2 percent at one time or the other patronize private borehole services away from their residences. 33.9 percent of respondents also have alternatives to the CRSWBL service because of doubts in the availability and quality of the water. Only 1.3 percent of the respondents have pipe-borne water as frequent as every hour of the day, 4.9 percent have water on daily basis, 44.3 percent have water at least once every week and 34.7 percent barely have pipe-borne water and thus resort to other sources of water.

\subsection{Varying Levels of Access to Pipe-Borne Water}

To explain the level of geographic access to pipe-borne water in the area, the UNPD (2000) specified the acceptable distance within which an individual can travel to acquire water as $200 \mathrm{~m}$. Any farther distance is deemed inappropriate, at which point, water can be said to be inaccessible. The results showed that 57.2 percent of respondents travel within permissible limits to get water from their 


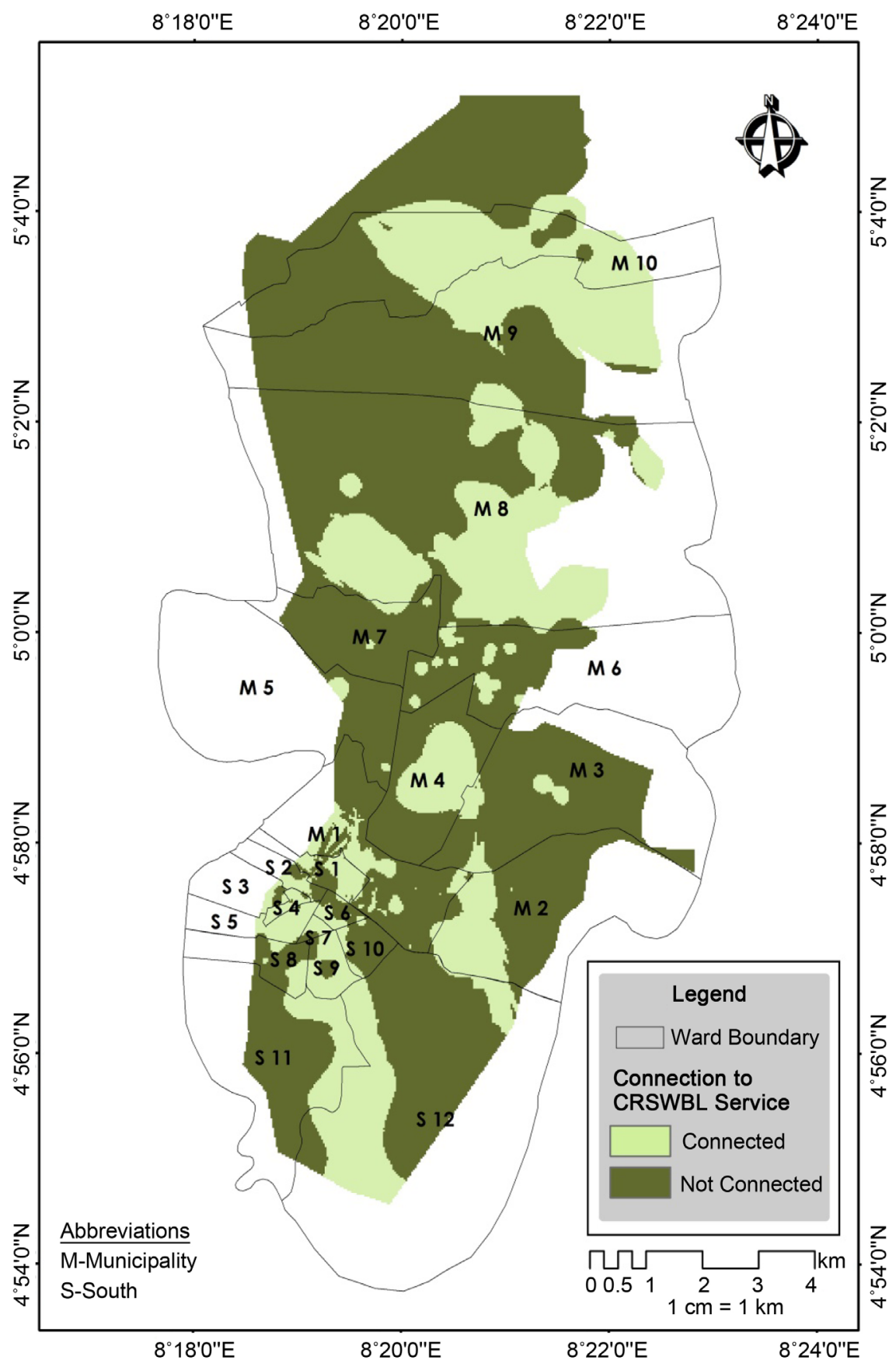

Figure 2. Residents connected to pipe-borne water service in the Metropolis (Source: Authors field work, 2016).

alternate sources while 38.1 percent travel more than $200 \mathrm{~m}$ to acquire water. Figure 3 is a map showing the pattern of travel to alternate sources of water by distance. The farthest travels, more than the $200 \mathrm{~m}$ standard was done in Calabar South Wards 6, 8 and 11 as well as Municipality Wards 1 and 6.

According to [7], at least 30 litres of water should be available for an individual's use per day. WHO also stipulated a standard of 50 litres per person per day. In the Metropolis, as revealed, less than 1 percent of households use less than 20 


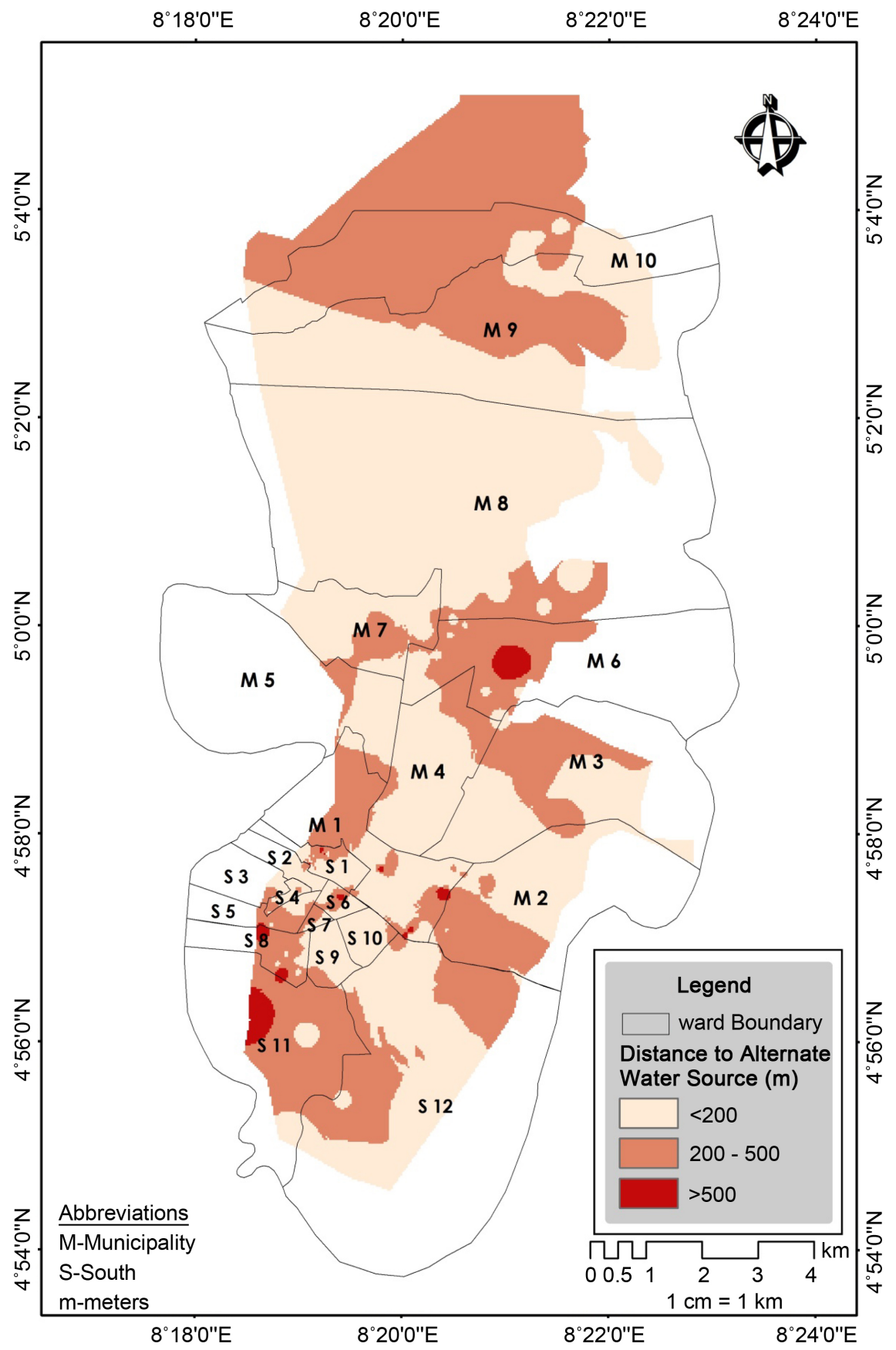

Figure 3. Average distance travelled by residents to alternate sources of water (Source: Authors field work, 2016).

litres, 9.8 percent use 20 to 40 litres on average daily, 18.8 percent use between 40 to 80 litres and 71.5 percent use more than 80 litres. The map of average daily water use represented in Figure 4 shows that most households in the Metropolis use more than 80 liters, while the lowest usage per household was recorded in Municipality Ward 3 and 8 as well as South Wards 2, 5 and 6 . With 56.8 percent of households having 4 - 6 persons, water use below 80 litres would be grossly inadequate to ensure good health and sanitation practices considering either the 


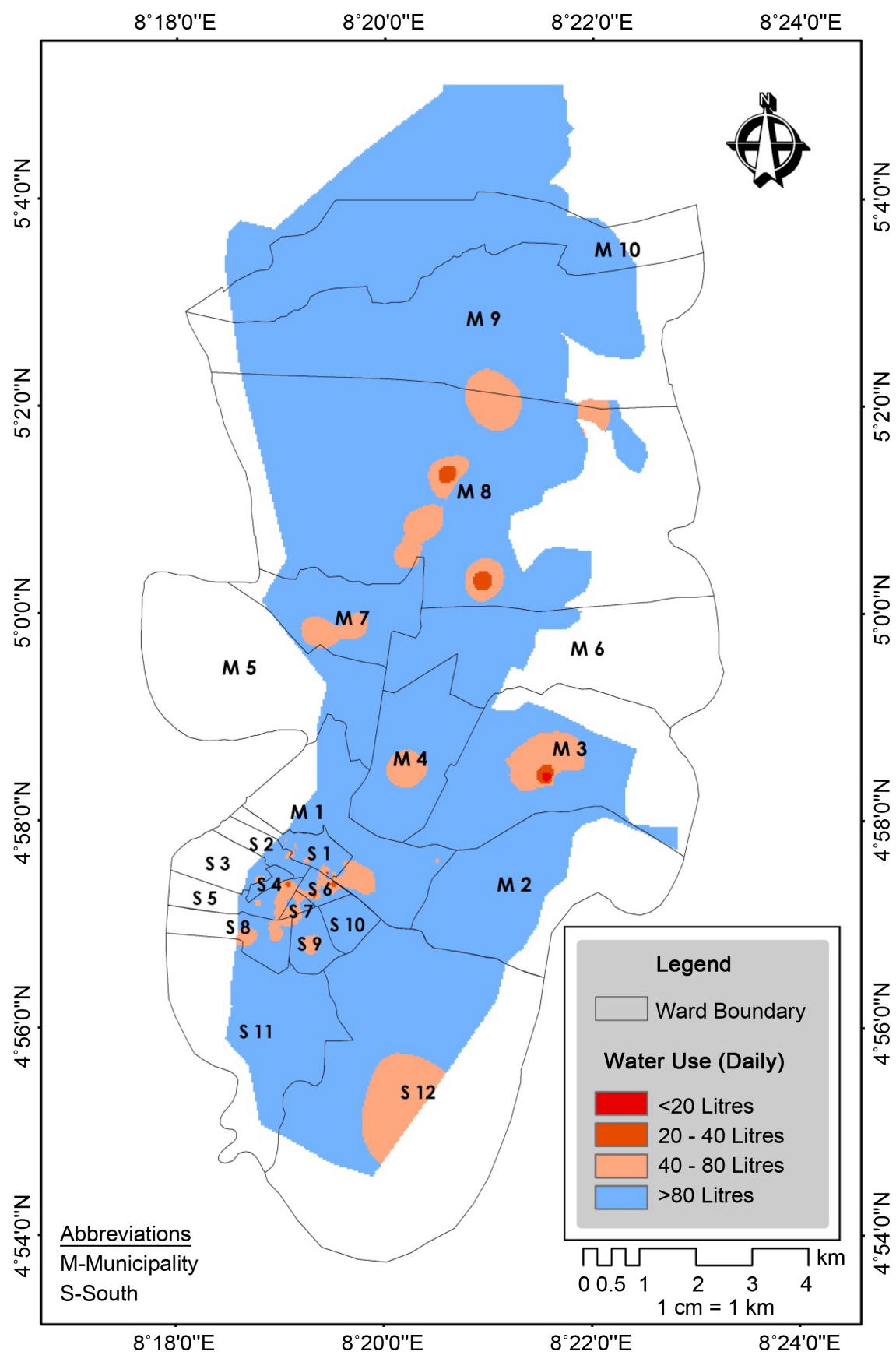

Figure 4. Average daily water use by households (Source: Authors field work, 2016).

\section{CRSTU or the WHO standard.}

The relationship between water use and household size of respondents in the Metropolis was assessed. From Table 2, the output of the Chi-square analyses shows that the Pearson Chi-square statistic $=9.577, p=0.144>0.05$. Here, the variables are independent, thus no significant statistical relationship between the number of persons in households sampled and average volume of water used daily by respondents in the Metropolis. The linear by linear association value of 0 depicts the weakest linear relationship between both variables. This does not 
Table 2. Chi-square tests for household size and average volume of water used daily.

\begin{tabular}{cccc}
\hline & Value & df & Asymp. Sig. (2-sided) \\
\hline Pearson Chi-Square & 9.577 & 6 & 0.144 \\
Likelihood Ratio & 8.701 & 6 & 0.191 \\
Linear-by-Linear Association & 0.000 & 1 & 0.997 \\
N of Valid Cases & 614 & & \\
\hline
\end{tabular}

Source: Authors field work, 2016.

mean there is zero relationship between the two variables. Rather, it means that there is a very weak linear relationship.

The reason for this independence in household size and water use is not far-fetched. It is most likely as a result of the fact that, in the Metropolis, households with more persons use similar volume of water as households with fewer persons. Thus, a higher number of persons do not necessarily imply more water use. This is buttressed by the fact that some areas with low and less dense population in the Metropolis such as Ward 8 of the Municipality exhibited high water usage (greater than 80 litres) as much as high populated and denser areas such as Ward 5 of Calabar South as pictured in Figure 4. Where a larger number of persons use less volume of water, hygienic conditions would tend to be low. It connotes that residents in areas such as the high density wards of Calabar South, are more disposed to water-borne diseases than their counterparts in the Municipality, especially when there is more water use in the former than the latter.

Since water is an inevitable resource that is most times acquired at a cost, either from government or private sources, an assessment of the relationship between the average income of respondents in the Metropolis and their water usage pattern becomes necessary. A summary of the Chi-square analyses in Table 3 shows that the Pearson Chi-square statistic $=29.82, p=0.03<0.05$. In this scenario, the variables are dependent, thus a significant statistical relationship exist between the average volume of water used daily by respondents in the Metropolis and their income.

A significant relationship between water use and income level, on the one hand implies that a higher income would denote more use of water. It is expected that a higher income earner would have a larger house, kitchen, more rooms and probably a car and thus would spend more on water, since more volume would be required. On the other hand, water has become so necessary that in the Metropolis, people use water no matter their financial status. Thus that a low income earner uses as much water as a high income earner, although not more. This must have been informed by the high literacy level in the area. The people are informed of the importance of water and are not limited by their resources. The health implication is that water borne diseases among the respondents were minimal with only 18.9 percent having experienced any related disease in the past few months. 
Table 3. Chi-square tests for average monthly income and average volume of water used daily.

\begin{tabular}{cccc}
\hline & Value & df & Asymp. Sig. (2-sided) \\
\hline Pearson Chi-Square & 29.820 & 12 & 0.003 \\
Likelihood Ratio & 27.295 & 12 & 0.007 \\
Linear-by-Linear Association & 8.447 & 1 & 0.004 \\
N of Valid Cases & 614 & &
\end{tabular}

Source: Authors field work, 2016.

Financial access to pipe-borne water can be measured by residents expenditure on government provided water and what is spent on alternate sources. According to the UN (2011), the expenditure on water services should not exceed 5 percent of a household's income, such that the service does not affect peoples' capacity to acquire other essential goods and services. As derived from the field survey, 31.6 percent of households spend between 1000 Naira to 2000 Naira on pipe-borne water monthly. 6.7 percent spend as much as 3000 Naira and just a little above 10 percent spend less than 1000 Naira on the service. Sadly, 50.2 percent do not patronize the service thereby reducing the revenue accruable by the CRSWBL. As symbolized in Figure 5, a number of respondents in Calabar South Wards 1, 2 and 6 as well as Municipality Wards 2, 4, 6, 7 and 8 spend above 3000 Naira on pipe-borne water monthly.

Alternatively, on an average, respondents spend so much to acquire water from other sources. Statistics from the field survey showed further that 53.1 percent of households spend as much as 2000 Naira monthly to buy water from privately operated boreholes in their neighbourhoods. Another 19.5 percent spend between 2000 Naira and 3000 Naira due to higher demands. The map presented in Figure 6 shows that some residents in Calabar South Wards 3, 4 and 5 spend more on acquiring water from sources different from CRSWBL, spending as much as 4000 Naira monthly. Expenditures on pipe-borne water and other water sources showed obvious differences. More residents spend more to acquire water from other sources. This is so because the government provided water is known to be cheaper than the privately operated sources owned by capitalists whose major aim is to make profit. It is worthy to note that some residents travel with vehicles, tricycles or other automobile means to acquire water, thus increasing the expenses they accrue in their bid to access the resource.

No doubt, relationship exists between expenditure on pipe-borne water and income of respondents in the area. The result of the Chi-square analyses as portrayed in Table 4 shows that the Pearson Chi-square statistic $=74.491, p=0.0<$ 0.05 . Here, the variables are dependent, thus a significant statistical relationship exist between the average monthly expenditure of pipe-borne water by respondents in the Metropolis and their income. Expenditure on pipe-borne water as buttressed by the Chi-square test is influenced by the income of the residents. It is expected that since income influences the volume of water used by respondents, it would also determine the amount that would be spent on water in the 


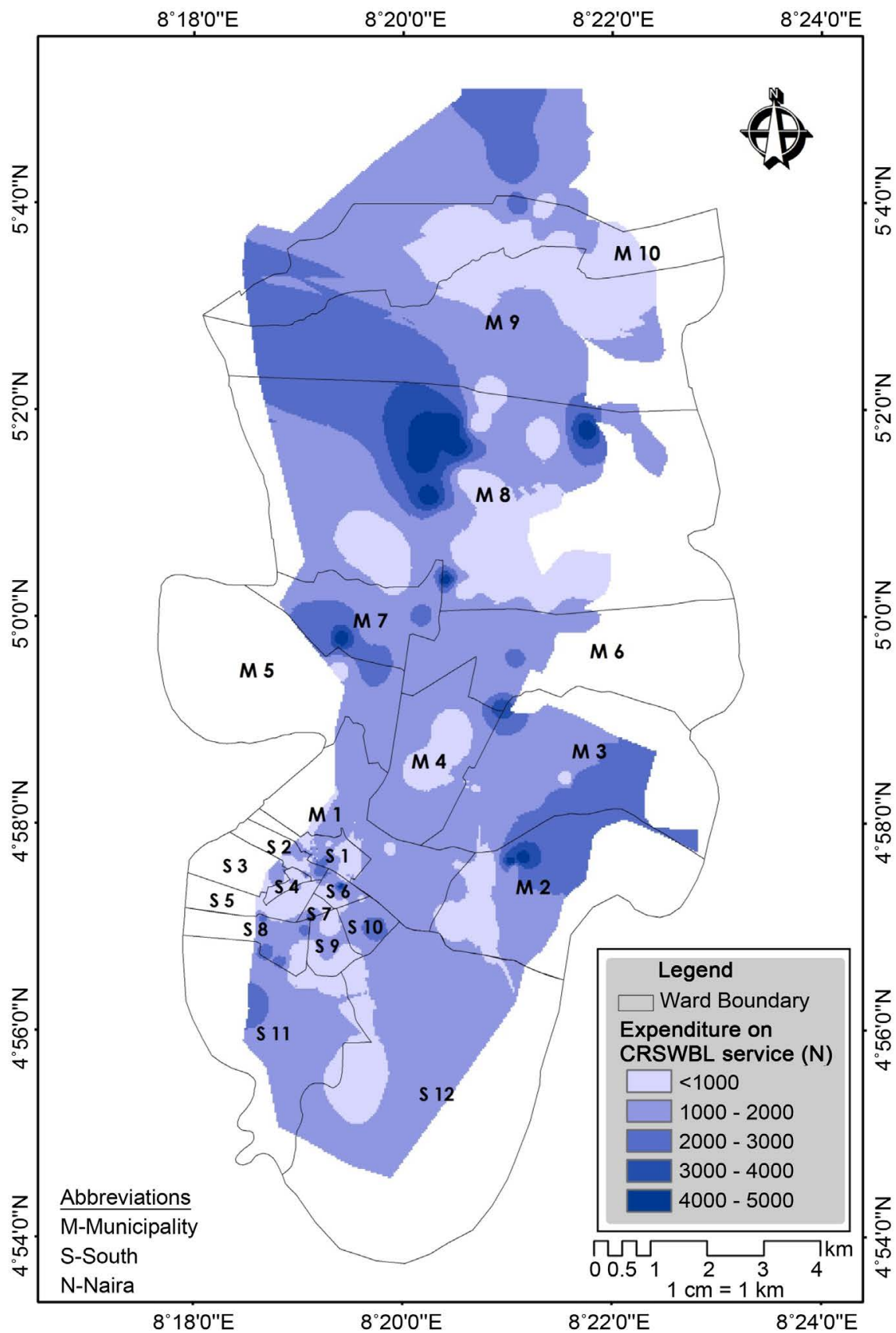

Figure 5. Expenditure on CRSWBL pipe-borne water by households (Source: Authors field work, 2016).

same month.

In a nutshell, most respondents were very unsatisfied with the pipe-borne water service. A summary of the overall quality of access as perceived by the respondents revealed that 87.3 percent of households surveyed think pipe-borne water is inadequate and needs to be improved upon. Only 0.5 percent were of the notion that the service is very adequate while 7.2 percent argued that it was very inadequate. In the same vein, 88.8 percent representing 545 of the respondents would not pay more even if the service is improved while 11.2 percent 


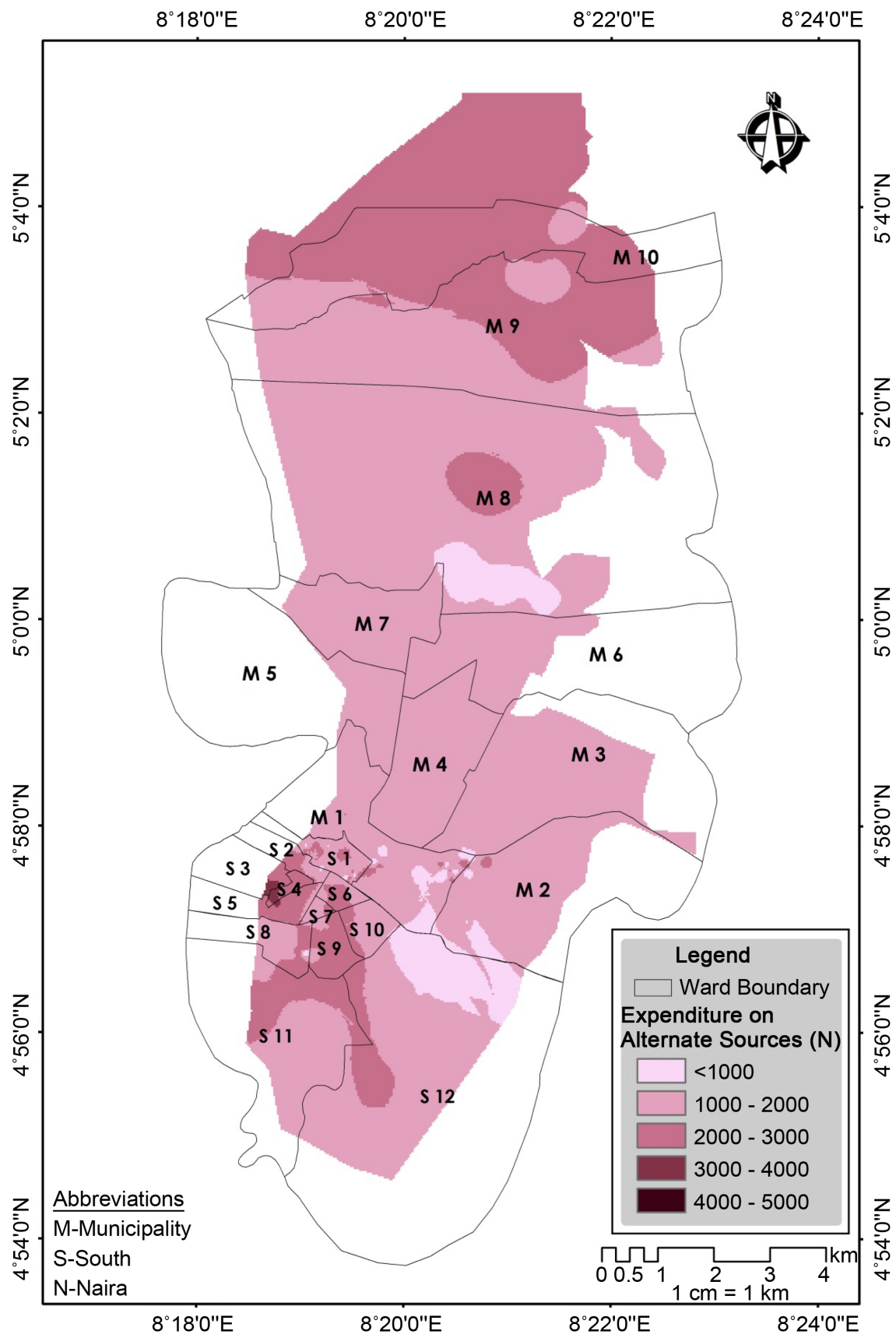

Figure 6. Expenditure on alternate water sources (Source: Authors field work, 2016).

Table 4. Chi-square tests for expenditure of respondents on pipe-borne water and income of respondents.

\begin{tabular}{cccc}
\hline & Value & df & Asymp. Sig. (2-sided) \\
\hline Pearson Chi-Square & 74.491 & 20 & 0.000 \\
Likelihood Ratio & 59.912 & 20 & 0.000 \\
Linear-by-Linear Association & 19.426 & 1 & 0.000 \\
N of Valid Cases & 614 & & \\
\hline
\end{tabular}

Source: Author's field work, 2016. 
would not mind paying more for an adequate service. A total of 68.7 percent of respondents were willing to pay more however would not pay more for a better service. Unsurprisingly, 16.8 percent want the service totally free, even when it is improved upon.

Following the revelation that the overall access to pipe-borne water in the Metropolis was inadequate after specific assessments of the presence, frequency, quality, and cost of the service, it becomes necessary to find out how the four dimensions of access contribute in explaining access to pipe borne water and which dimensions play the most significant role in explaining the overall access to the service in the area. The result returned by the multi-nomial logistic regression as shown on Table 5 revealed that the final model has a combined effect which is significant, $\chi^{2}(30)=93.455, p=0.00$. Thus a conclusion that a combined effect of the model of availability, geographic, financial and acceptability significantly contributes in measuring access to pipe-borne water in the Calabar Metropolis. However, as shown on Table 6, in as much as a combined effect of all the dimensions contributed in explaining access to pipe-borne water in the area, availability and financial dimensions fared better with significant alpha values of 0.031 and 0.001 respectively. This implies that connection to the service and presence of water was deemed somewhat manageable by the residents, whereas more concern should be given to the frequency of supply and cost of the service.

\section{Conclusions}

The study investigated access to pipe-borne water in Calabar Metropolis. A

Table 5. Regression model fitting information.

\begin{tabular}{ccccc}
\hline \multirow{2}{*}{ Model } & Model Fitting Criteria & \multicolumn{3}{c}{ Likelihood Ratio Tests } \\
\cline { 2 - 5 } & -2 Log Likelihood & Chi-Square & df & Sig. \\
\hline Intercept Only & 236.725 & & & \\
Final & 143.270 & 93.455 & 30 & 0.000 \\
\hline
\end{tabular}

Source: Authors field work, 2016.

Table 6. Likelihood ratio tests for regression.

\begin{tabular}{ccccc}
\hline & Model Fitting Criteria & \multicolumn{2}{c}{ Likelihood Ratio Tests } \\
\cline { 2 - 5 } Effect & $\begin{array}{c}\text {-2 Log Likelihood of } \\
\text { Reduced Model }\end{array}$ & Chi-Square & df & Sig. \\
\hline $\begin{array}{c}\text { Intercept } \\
\text { Availability (Water Frequency) }\end{array}$ & 143.270 & 0 & 0 & \\
Acceptability & 165.89 & 22.62 & 12 & 0.031 \\
$\begin{array}{c}\text { (Perception of Availability) } \\
\text { Financial (Perception of Cost) }\end{array}$ & 157.31 & 14.039 & 9 & 0.121 \\
$\begin{array}{c}\text { Geographic } \\
\text { (CRSWBL Connection) }\end{array}$ & $167.045^{\mathrm{b}}$ & 23.775 & 6 & 0.001 \\
\hline
\end{tabular}

Source: Authors field work, 2016. 
summary of the results showed that access to the pipe borne water service was generally limited although some variations were noticeable within the area. The unavailability and inconsistency of the service in most parts of the Metropolis imply a reliance on alternate sources of water by the residents. While some resorted to boreholes, others resorted to boreholes away from their homes, hand-dug wells and streams. There were also spatial variation in the connection to the service, supply, consumption and expenditure on the pipe-borne water service in the area. Connection to the service showed not to guarantee access and the overall quality of access as perceived by the residents was revealed to be poor and the need for an improvement in the service was emphasized.

More precisely, an assessment of the relationship between the volume of water used by residents and their income level showed that both variables were statistically related. This dependency was also noticeable in the assessment of existing relationship between expenditure on pipe-borne water and income of respondents. However, the assessment of pipe-borne water use versus household size proved insignificant. Additional, while initial results showed insufficiency in the water board service, revelations from the analysis pointed out that a combined effect of the regression model of all the dimensions significantly contribute in measuring access to pipe-borne water in the Metropolis and availability and financial dimensions fared better in explaining access to the service in the area.

In view of the findings from this study, it becomes evident that the Nigerian government and the administrators of Calabar metropolis need to intensify efforts in her mandate of provision of water to urban and rural areas as people are not satisfied with the service and have sought to alternate sources of water with some travelling more than the permissible distance to acquire water. Municipal water provision is a communal trust of common wealth, upon which every citizen relies and draws for prospects and day to day socio economic opportunities.

\section{Recommendations}

On the shoulder of the government lies the major burden of making pipe-borne water accessible to the dwellers rural and city dwellers. The administrators of Calabar metropolis and the Nigerian government at large must emulate the developed world in its provision of water through increasing access to portable water by locating, developing and managing new sources, especially by turning to more sustainable options such as reuse of waste-water, while continuing to use older methods and improve on water distribution which is a very vital aspect of making water accessible to the populace.

CRSWBL should not only increase the volume of water supplied but also ensure that more households are connected to the service and the frequency of supply up-surged. The spatial variation in socio-economic and demographic characteristics should also be considered for effective for water supply management. Care should be taken in the volume of water supplied to different parts of the Metropolis since every area has its unique attributes. The population density 
of the city, water needs and financial capability of residents of different areas in the city should serve as a guide to the water board for water distribution management.

Likewise, all the dimensions of access should be considered in executing pipe-borne water services. For example, when there is more focus on connecting households to the service without commensurate supply of water at affordable rates, access is impeded. Periodic studies should be carried out periodically to know where there are lapses in service provision. More concern should also be given to the frequency of supply and cost of the service as they fared better in explaining access to pipe-borne water in the study area.

\section{References}

[1] United Nations Population Division (2000) Charting the Progress of Populations. 67-71. http://www.un.org/esa/population/pubsarchive/chart/12.pdf

[2] WHO (2003) The Right to Water. Office of the High Commissioner for Human Rights (OHCHR), Centre on Housing Rights and Evictions (COHRE), Water Aid, Centre on Economic, Social and Cultural Rights. http://www.un.org/esa/population/pubsarchive/chart/12.pdf

[3] Cross River State Technical Unit (CRSTU) (2009) Cross River State Water Supply and Sanitation Policy Report. Final Draft. http://www.crswaterboard.com/documents/crs_final_draft_wss_policy.doc

[4] United Nations (2011) The Human Right to Water and Sanitation: Media Brief. UN-Water Decade Programme on Advocacy and Communication and Water Supply and Sanitation Collaborative Council.

[5] Uneke, C.J., Ogbonna, A., Ezeoha, A., Oyibo, P., Onwe, F. and Ngwu, B. (2008) The Nigeria Health Sector and Human Resource Challenges. The Internet Journal of Health, 8, 1-5.

[6] Ikelegbe, O. and Okoruwa, O.A. (2007) Meeting the Demand for Pipe Borne Water Supply in an Urban Environment: The Case of Benin City. Research Gate. http://www.researchgate.net/publication/245869609

[7] Peters, D.H., Anu, G., Gerry, B., Damian, G.W., William, R.B. and Hafizur, R. (2008) Poverty and access to Health Care in Developing Countries. Annals of the New York Academy of Sciences, 1136, 161-171. https://doi.org/10.1196/annals.1425.011

[8] Shrestha, J. (2010) Evaluation of Access to Primary Healthcare; A Case Study of Yogyakarta, Indonesia. M.Sc. Thesis Submitted to the International Institute for Geo-Information and Earth Observation.

[9] WHO/UNICEF (2014) Joint Monitoring Programme for Water Supply and Sanitation Report. http://www.wssinfo.org/

[10] Vanguard News (2015) Water's Like Electricity in Calabar: No Service, Huge Bills, by Ike Uchechukwu.

http://www.vanguardngr.com/2015/04/waters-like-electricity-in-calabar-no-servicehuge-bills/

[11] World Bank (2015) Population Growth: Annual Percentage. http://www.data.worldbank.org/indicatpr/sp.pop.grow?locations=ng

[12] Amori, A. and Makinde, A. (2012) Evaluation of Access to Public Water Supply in 
Two Major Cities in Nigeria. American Journal of Environmental Engineering, 2, 148-151. https://doi.org/10.5923/j.ajee.20120206.01

[13] Eja, E.I., Otu, J.E., Joy, E.A. and Edet, E.O. (2011) Urban Water Supply as a Catalyse for Socio-Economic Transformation of Port Harcourt City, Nigeria. International Journal of Humanities and Social Science, 1, 89-92.

[14] Olusegun, A.A. (2015) Socio-Economic Analysis of Pipe-Borne Water Supply in Mubi Metropolis of Adamawa State, Nigeria. International Journal of Business and Social Science, 6, 194.

[15] Ajadi, B.S. (2010) Portable Water Availability and Consumption Pattern in Ilorin Metropolis, Nigeria. Global Journal of Human Social Science, 10, 44-50.

[16] Bankole, B.O. (2010) The Geographical Distribution of Water Supply in Ekiti State. Africa Research Review, 4, 71-79. https://doi.org/10.4314/afrrev.v4i2.58291

[17] Peloso, M. and Morinville, C. (2014) "Chasing for Water": Everyday Practices of Water Access in Peri-Urban Ashaiman, Ghana. Water Alternatives, 7, 121-139.

[18] Kennedy, P.M. (2006) An Analysis of the Relationship between Water Accessibility, Use and Health in Muthara, Kenya. A Report Submitted in Partial Fulfillment of the Requirements for the Degree of Master of Science in Environmental Engineering, Michigan Technological University.

[19] Krebs, M. (2010) Nigeria Reports Water Scarcity across Numerous States. http://www.digitaljournal.com/article/301656

[20] Chia, V.D., Ijir, S.T., Iwar, R. and Ndulue, E.L. (2014) The Contending Issues of Domestic Water Supply in Makurdi Metropolis, Benue State, Nigeria. Civil and Environmental Research, 6, 89-94.

[21] Ohwo, O. and Abotutu, A. (2014) Access to Potable Water Supply in Nigerian Cities Evidence from Yenagoa Metropolis. American Journal of Water Resources, 2, 31. https://doi.org/10.12691/ajwr-2-2-1

[22] Lawal, O. and Bashorun, J. (2015) Access to Safe Water in Akure: A Paradox in Nigerian Urbanized Regions. International Journal of Emerging Knowledge, 3, 39.

[23] Ezenwaji, E.E., Awopeju, A.K., Otti, V.I. and Eduputa, B.M. (2014) Spatial Patterns of Residential Water Supply Accessibility Levels in Anambra State, Nigeria. International Journal of Engineering Research and Applications, 4, 326.

[24] Samuel, U.U., Egbai, O.O., Eric, J.N., Ewa, E.E. and Uquetan, U.I. (2011) Cost Analysis of Domestic Water Consumption in Calabar Metropolis, Cross River State, Nigeria. Journal of Human Ecology, 36, 199-203.

[25] Njoku, C.G., Okon, I., Itu, P.-C. and Otese, A.V. (2017) Population Growth and Pipe-Borne Water Supply in Calabar Metropolis: Finding the Balance. International Journal of Research in Geography, 3, 51-59.

[26] Ajibade, L.T., Ayeni, O.O. and Ahmed, I.M. (2012) Public-Private-People Partnership for Sustainable Portable Water Supply System in Nigeria. Journal of Sustainable Development in Africa, 14, 209.

[27] Abaje, I.B., Ati, O.F. and Ishaya, S. (2009) Nature of Potable Water Supply and Demand in Jema'a Local Government Area of Kaduna State, Nigeria. Research Journal of Environmental and Earth Sciences, 1, 20.

[28] Njoku, C.G., Okon, I., Okpiliya, F., Agbor, A.A. and Ekwok, I. (2017) Epanet Spatial Modelling for Equitable Pipe-Borne Water Distribution in Calabar Metropolis, Cross River State, Southern Nigeria. International Journal of Science, Environment and Technology, 6, 2655-2673. 
[29] Dixon, C. and Leach, B. (1977) Sampling Methods for Geographical Research, Concepts and Techniques in Modern Geography. Geo Abstracts, University of East Anglia, Norwich, NR4 7TJ. 